Original scientific paper

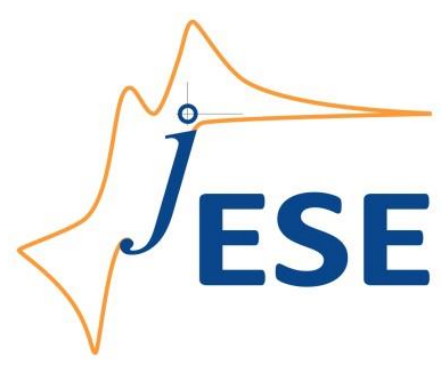

Open Access : : ISSN 1847-9286

www.jESE-online.org

\title{
Electrocoagulation of whey acids: anode and cathode materials, electroactive area and polarization curves
}

Francisco Prieto-García ${ }^{1}$, Judith Callejas-Hernández ${ }^{1}$, Judith Prieto-Méndez ${ }^{2, \bigotimes}$, Yolanda Marmolejo-Santillán ${ }^{1}$

${ }^{1}$ Área Académica Química, Universidad Autónoma del Estado de Hidalgo. Carret. Pachuca-

Tulancingo, km. 4.5, C. P. 42076. Mineral de la Reforma. Hidalgo. México

${ }^{2}$ Área Académica de Agronomía, Universidad Autónoma del Estado de Hidalgo. Carret. Pachuca-

Tulancingo, km. 4.5, C. P. 42076. Mineral de la Reforma. Hidalgo. México

${ }^{\square}$ Corresponding author: jud 292003@yahoo.com.mx

Received: March 30, 2017; Revised: June 6, 2017; Accepted: June 6, 2017

\begin{abstract}
Anode $\left(\mathrm{Al}\right.$ and $\mathrm{Fe}$ ) and cathode (graphite and $\mathrm{Ti} / \mathrm{RuO}_{2}$ ) materials have been tested for electrocoagulation (EC) and purification of the acid whey. The electroactive areas (EA) of electrodes were calculated by the double layer capacitance method. Experiments were performed by cyclic voltammetry, chronoamperometry and polarization experiments. Among cathodic materials, the $\mathrm{Ti} / \mathrm{RuO}_{2}$ electrode showed higher $\mathrm{EA}\left(2167 \mathrm{~cm}^{2}\right)$ than graphite $\left(1560 \mathrm{~cm}^{2}\right)$. The Fe anode was found more stable than Al with greater charge transfer carried out in less time. Correlation of these results with those obtained during preliminary tests confirmed high removals (79 \%) in $8 \mathrm{~h}$. For the Al electrode, $24 \mathrm{~h}$ were required to achieve efficiency of $49 \%$.
\end{abstract}

\section{Keywords}

Electrocoagulation, electrode materials, acid whey, electroactive area, capacitance, Tafel slopes

\section{Introduction}

The electrodes are indispensable components of any electrochemical cell because just on their surface the processes of oxidation-reduction of the species occur together with other reactions carried out during electrolysis [1,2]. When an electrocoagulation (EC) process is applied, the electrodes must be cost-effective and easy to handle. In addition, the electrodes used as sacrificial anodes must also possess great dissolution power. The most frequent materials used for EC processes of different effluents with good removal efficiencies are aluminum ( $\mathrm{Al}$ ) and iron (Fe), but other materials such as steel $[3,4]$ have also been tested. 
In the present study, different materials acting as anodes ( $\mathrm{Al}$ and $\mathrm{Fe}$ ) and cathodes (graphite and $\mathrm{Ti} / \mathrm{RuO}_{2}$ ) are tested for the EC and purification of residual acid whey. The evaluation is performed with respect to the electroactive electrode area and through polarization curves.

\section{Methodology}

\section{Determination of electroactive area (EA) of electrodes}

Determination of real electroactive area (EA) was done for $\mathrm{Al}, \mathrm{Fe}$, graphite (G) and $\mathrm{Ti} / \mathrm{RuO} 2$ electrodes. The cyclic scanning voltammetry technique, exploring the BASI Epsilon EC potentiostat 2.13 USB was used. Experiments were performed in $0.1 \mathrm{M} \mathrm{KCl}$ solution acidified with $\mathrm{HCl}$ to maintain $\mathrm{pH} 4.7$, what simulates the initial $\mathrm{pH}$ of the acid whey $[5,6]$. The electroactive area of each electrode surface was calculated by the capacitance of the double layer, $C_{\mathrm{dl}}$, generated on the electrode in contact with an electrolyte [7].

A glass beaker $(2 \mathrm{~L})$ containing $0.1 \mathrm{M} \mathrm{KCl}$ solutions was used as the electrochemical cell in which the electrodes were immersed (Fig. 1). The electrodes were submerged to a height of $5 \mathrm{~cm}$, exposing a geometric area of approximately $100 \mathrm{~cm}^{2}$ to the solution. The dimensions of electrodes were as follows: $\mathrm{Al}(10.2 \times 10 \times 0.1 \mathrm{~cm})$, Fe $(10.1 \times 10 \times 0.2 \mathrm{~cm}), \mathrm{G}(8.2 \times 10 \times 1.2 \mathrm{~cm})$ and $\mathrm{Ti} / \mathrm{RuO}_{2}$ mesh $(10.5 \times 10 \times 0.1 \mathrm{~cm})$. Titanium $(\mathrm{Ti})$ mesh electrode $(10 \times 10 \times 0.1 \mathrm{~cm})$ and the saturated calomel electrode (SCE) served as the counter and reference electrode, respectively.

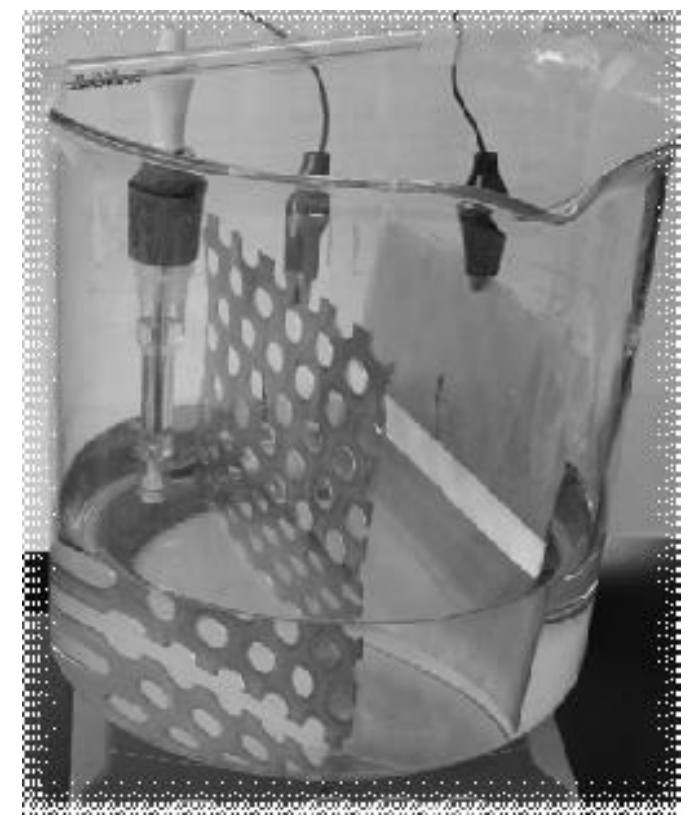

Figure 1. Glass cell containing Ti mesh counter and SCE reference electrodes used for determination of electroactive area of working electrodes ( $\left.\mathrm{Al}, \mathrm{Fe}, \mathrm{G}, \mathrm{Ti} / \mathrm{RuO} \mathrm{O}_{2}\right)$

Cyclic voltammetry experiments were performed at different scanning rates, $\mathrm{V}=10-100 \mathrm{mV} \mathrm{s}^{-1}$ in a potential window of $\pm 10 \mathrm{mV}$ around the equilibrium potential $\left(E_{0}\right)$. Anodic $\left(i_{\mathrm{a}}\right)$ and cathodic $\left(i_{\mathrm{c}}\right)$ currents were obtained as electrochemical responses to the potential change. The capacitive current $\left(i_{\text {cap }}\right)$ was calculated by means of equation (1), while $C_{\mathrm{dl}}$ value was calculated as the slope of linear relation obtained by presenting $i_{\text {cap }} v s . V$. The EA, is obtained by means of equation (2), where $C_{\text {st }}$ is the normal capacitance taken as $C_{\text {st }}=60 \mu \mathrm{F} \mathrm{cm}{ }^{-2}$ for roughened electrodes [7].

$$
i_{\text {cap }}=\frac{i_{\mathrm{a}}+i_{\mathrm{c}}}{2}
$$




$$
\mathrm{EA}=\frac{c_{\mathrm{dl}}}{c_{\mathrm{st}}}
$$

\section{Measurements of polarization curves}

With the polarization curves it is possible to determine the electrode of the highest oxidation capacity attained with consumption of the lowest energy. The potentioamperometric technique was explored using a sample of acid whey $(30 \mathrm{~mL})$ and geometrically smaller electrodes. The electrodes were submerged to a height of $2.0 \mathrm{~cm}$ and the exposed geometric areas were $6.96 \mathrm{~cm}^{2}$ (Al), $8.78 \mathrm{~cm}^{2}(\mathrm{Fe}), 4.65 \mathrm{~cm}^{2}(\mathrm{G})$ and $8.6 \mathrm{~cm}^{2}\left(\mathrm{Ti} / \mathrm{RuO}_{2}\right)$. The real electrode areas were determined following the methodology described above. Three-electrode glass cell was used and shown in Figure $2 \mathrm{a}$, where the working electrode is the $\mathrm{G}$ electrode, while Ti mesh and SCE served as the auxiliary and reference electrodes, respectively. Figure $2 b$ shows a three-electrode cell containing $30 \mathrm{~mL}$ of acid whey used for chronoamperometric experiments, performed by applying different overpotentials, $\eta$, defined by the equation (3) for 45 minutes.
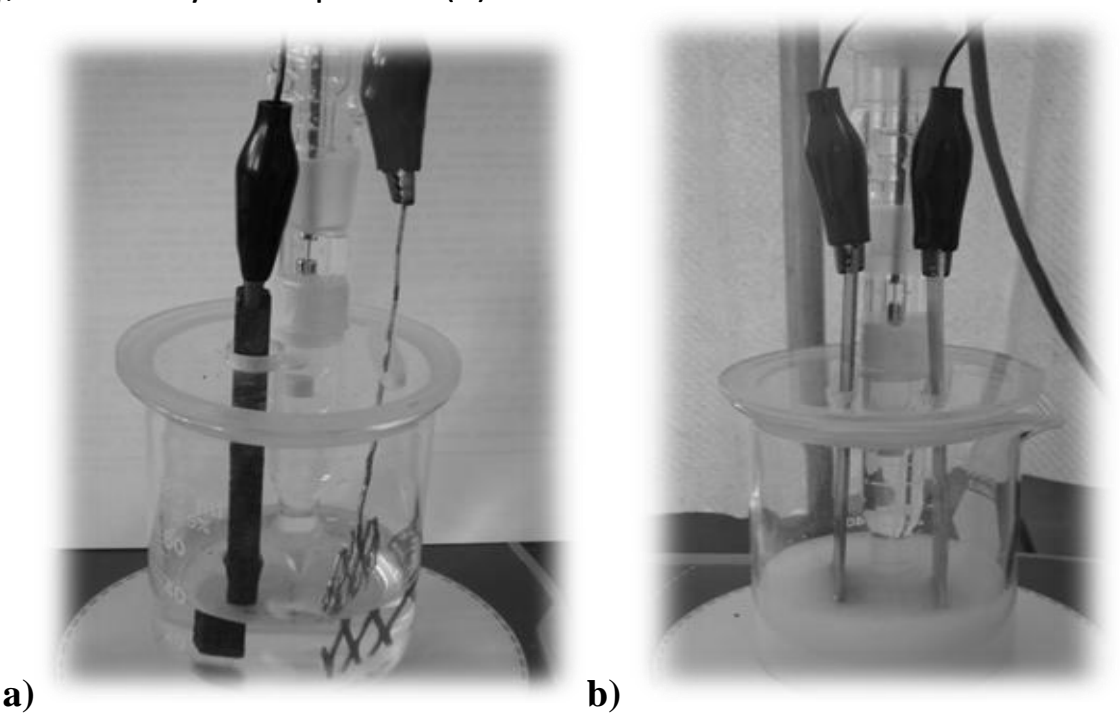

Figure 2. Three-electrode glass cell used for determination of electroactive area of small electrodes (G, Ti-mesh and SCE are the working, counter and reference electrodes) a).

Electrolytic cell containing $30 \mathrm{~mL}$ of acid whey for polarization measurements

(Al, Ti-plate and SCE are the working, counter and reference electrodes) b)

Constant stirring is maintained during the test to obtain the current $(i)$ in response. The current density ( $j$ ) is calculated by the equation (4).

$$
\begin{aligned}
& \eta=E_{\text {applied }}-E_{0} \\
& j=i / \text { EA }
\end{aligned}
$$

\section{Results and discussion}

\section{Determination of electroactive area (EA) of electrodes}

Cyclic voltammograms of $\mathrm{Al}, \mathrm{Fe}, \mathrm{G}$ and $\mathrm{Ti} / \mathrm{RuO}_{2}$ electrodes in $0.1 \mathrm{M} \mathrm{KCl}$ recorded at different scan rates $(v)$ are together with $i$ vs. $u$ curves shown in Figures 3-6. Numerical data for $i_{\text {cap }}$ determined by eq. (1) are collected in Table 1 . Contrary to Figures 3 and 4 that showed ordinary capacitive current responses of $\mathrm{G}$ and $\mathrm{Ti} / \mathrm{RuO}_{2}$ electrodes, in the case of $\mathrm{Al}$ and Fe electrodes presented in Figures 5 and 6 , the tendency is quite different. Lack from usual linear $i_{\text {cap }} v s . v$ response is particularly obvious for the Fe electrode and is probably due to the dissolution of electrode in acid medium. 

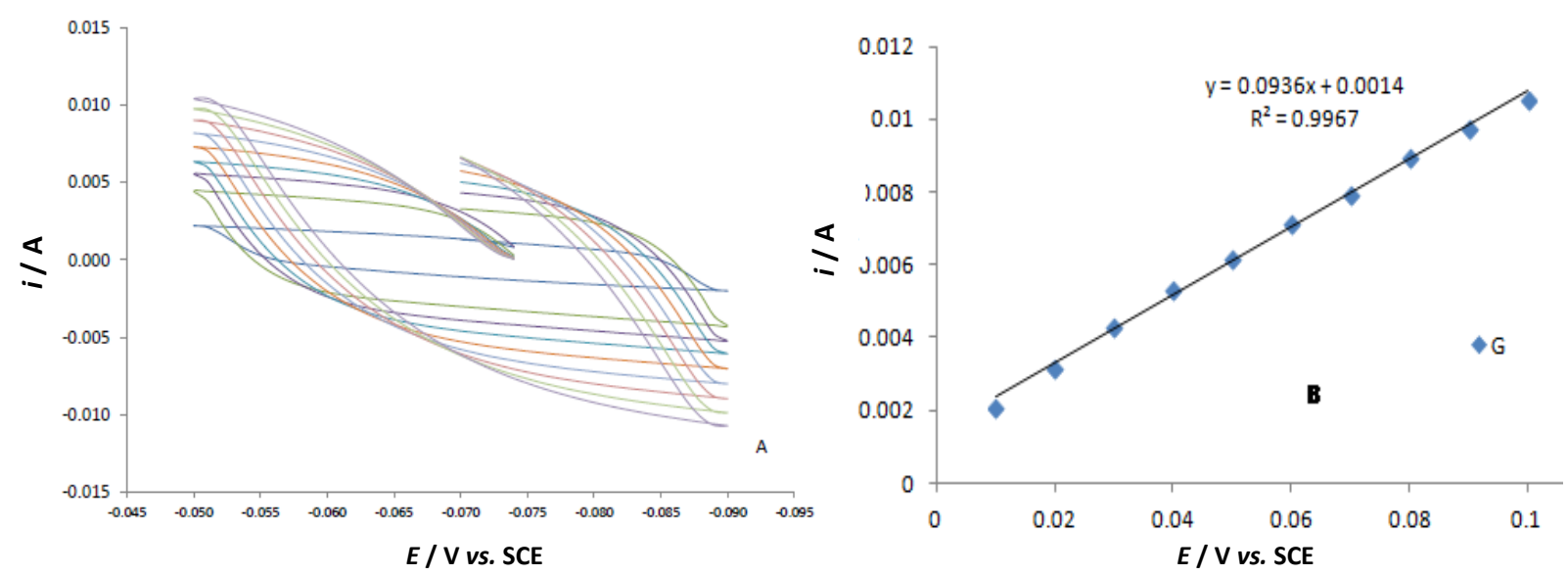

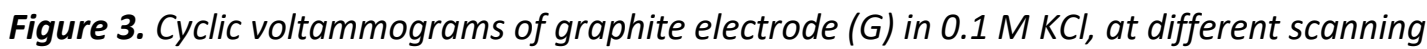
rates $\left(\mathrm{V}=0.01\right.$ to $\left.0.10 \mathrm{~V} \mathrm{~s}^{-1}\right)(A)$. $\mathrm{i}_{\text {cap }} v s . \mathrm{v}(B)$
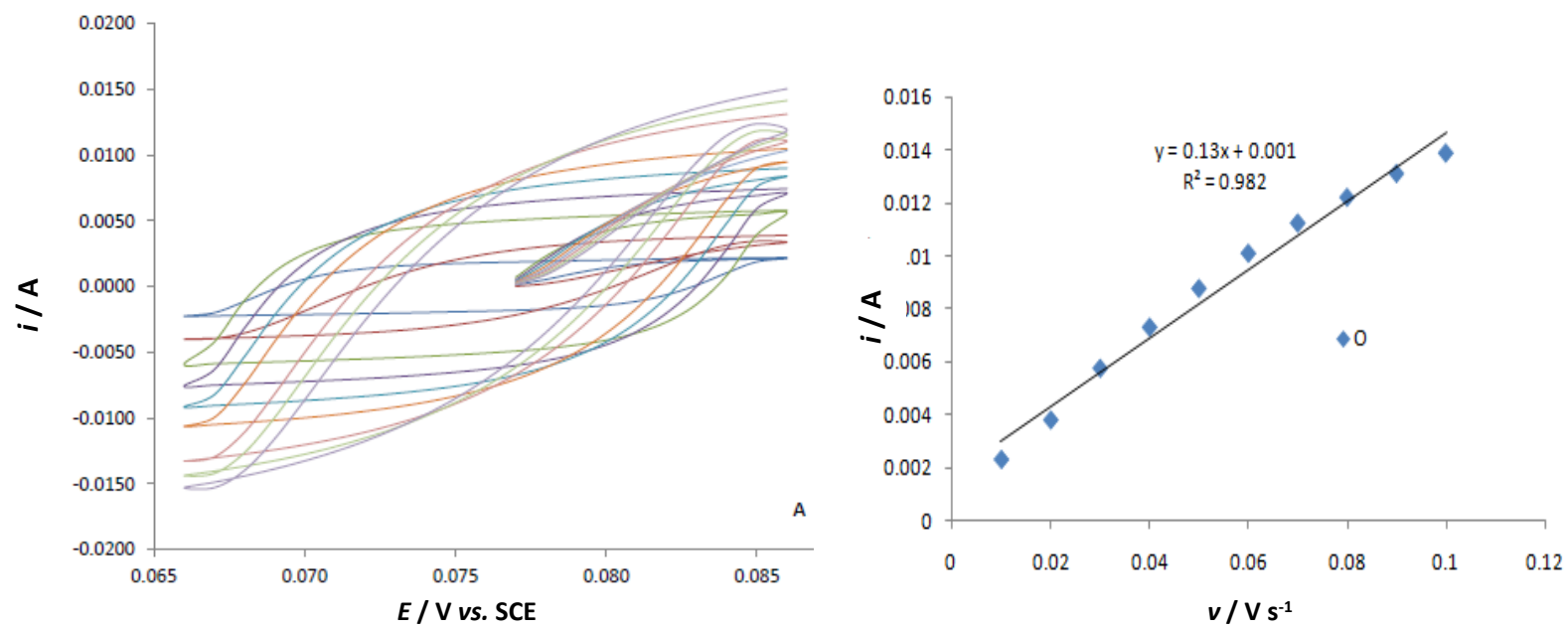

Figure 4. Cyclic voltammograms of $\mathrm{Ti}^{\prime} / \mathrm{RuO}_{2}$ electrode in $0.1 \mathrm{M} \mathrm{KCl}$ at different scanning rates $\left(\mathrm{v}=0.01\right.$ to $\left.0.10 \mathrm{~V} \mathrm{~s}^{-1}\right)(A)$. $\mathrm{i}_{c a p} \mathrm{vs} . \mathrm{v}(B)$
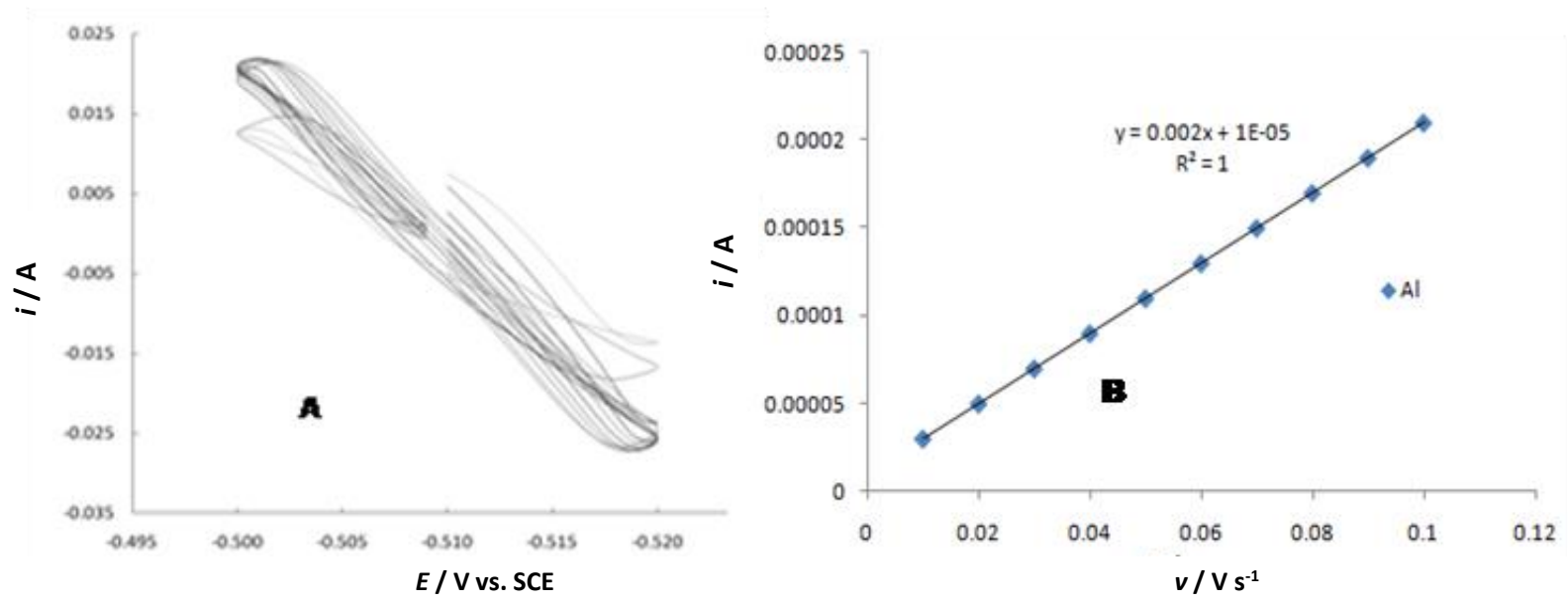

Figure 5. Cyclic voltammograms of Al electrode in $0.1 \mathrm{M} \mathrm{KCl}$ at different scanning rates

$$
\left(\mathrm{v}=0.01 \text { to } 0.10 \mathrm{Vs}^{-1}\right)(A) \text {. } \mathrm{i}_{c a p} \mathrm{vs} \text {. } \mathrm{v}(B)
$$

The electroactive area (EA) of the working electrode represents the number of active sites where the electron transfer takes place and is usually estimated as the real electrode area (Areal) defined by eq. (2). EA can increase or decrease with respect to the geometric area, what is mainly due to the modification of the electro-active electrode surface. When an EC process is carried out, the anode ( $\mathrm{Al}$ or $\mathrm{Fe}$ ) undergoes oxidation reaction, which leads to the release of metal ions (sacrificial 
anode) and concomitant dissolution process [4,8-11]. causing diminishing of the surface area. At the other hand, increase of the EA could also happen due to the porosity induced by the EC process.
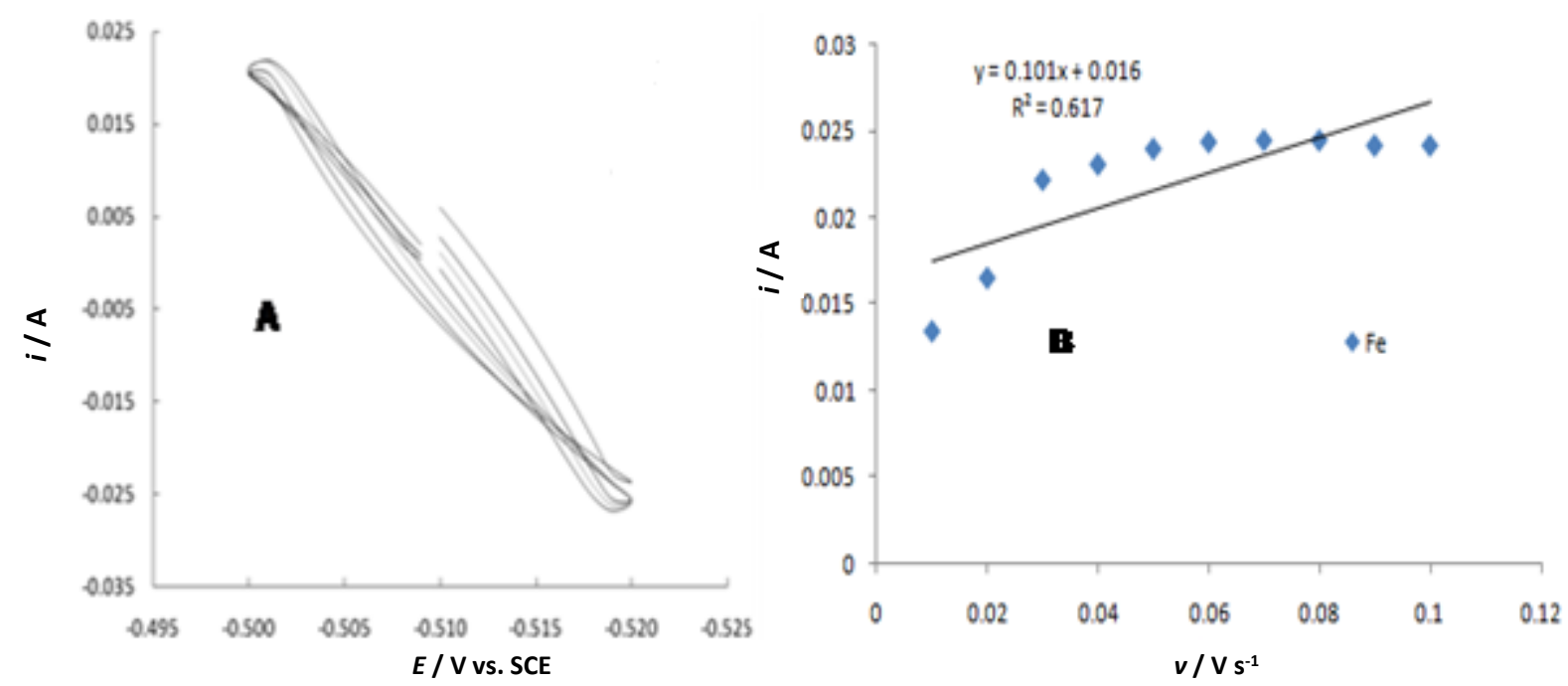

Figure 6. Cyclic voltammograms of Fe electrode in $0.1 \mathrm{M} \mathrm{KCl}$ at different scanning rates

$$
\left.\left(\mathrm{v}=0.01 \text { to } 0.10 \mathrm{~V} \mathrm{~s}^{-1}\right)(A) \text {. } \mathrm{i}_{\text {cap }} \mathrm{vs} . \mathrm{v} B\right)
$$

Table 1. Capacitive currents $\left(\mathrm{i}_{\text {cap }}\right)$ for different EC electrodes at different scanning rates $\mathrm{v}$

\begin{tabular}{lcccc}
\hline \multirow{2}{*}{$V / \mathrm{Vs}^{-1}$} & \multicolumn{4}{c}{$i_{\text {cap }} / \mathrm{A}$} \\
\cline { 2 - 5 } & $\mathrm{G}$ & $\mathrm{Ti}^{\mathrm{RuOO}}{ }_{2}$ & $\mathrm{Al}$ & $\mathrm{Fe}$ \\
\hline 0.01 & 0.00209 & 0.00229 & 0.00003 & 0.0134 \\
0.02 & 0.00318 & 0.00378 & 0.00005 & 0.0165 \\
0.03 & 0.00434 & 0.00573 & 0.00007 & 0.0222 \\
0.04 & 0.00538 & 0.00728 & 0.00009 & 0.0231 \\
0.05 & 0.00623 & 0.00874 & 0.00011 & 0.0240 \\
0.06 & 0.00718 & 0.01007 & 0.00013 & 0.0244 \\
0.07 & 0.00799 & 0.01121 & 0.00015 & 0.0245 \\
0.08 & 0.00899 & 0.01218 & 0.00017 & 0.0245 \\
0.09 & 0.0098 & 0.01308 & 0.00019 & 0.0242 \\
0.10 & 0.01055 & 0.01385 & 0.00021 & 0.0242 \\
\hline
\end{tabular}

Double-layer capacitance $\left(C_{\mathrm{dl}}\right)$ and EA values, calculated using data in Table 1 and eq. (2), are summarized in Table 2.

Table 2. Real area $(E A)$ and capacitance $\left(C_{\text {all }}\right)$ of different electrodes for the electrocoagulation process

\begin{tabular}{ccccccc}
\hline Electrodes & Equation & $\mathrm{R}^{2}$ & $C_{\mathrm{dll}} / \mathrm{F}$ & $\mathrm{EA}, \mathrm{cm}^{2}$ & $\mathrm{GA}^{*}, \mathrm{~cm}^{2}$ & Roughness factor \\
\hline $\mathrm{G}$ & $y=0.0936 x+0.0014$ & 0.9967 & 0.0936 & 1,560 & 103.84 & 15.03 \\
$\mathrm{Ti}_{\mathrm{RuO}} \mathrm{R}_{2}$ & $y=0.130 x+0.0010$ & 0.9821 & 0.130 & 2,167 & 107.05 & 20.24 \\
$\mathrm{Al}$ & $y=0.002 x+10^{-5}$ & 1.0000 & 0.0020 & 33.3 & 104.02 & 0.32 \\
$\mathrm{Fe}$ & $y=0.101 x+0.016$ & 0.617 & 0.1010 & 1,689 & 105.02 & 16.1 \\
\hline
\end{tabular}

$\mathrm{GA}^{*}$ - Geometric area

It is obvious from Table 2 that $\mathrm{Ti} / \mathrm{RuO}_{2}$ electrode showed the largest $\mathrm{EA}\left(2,167 \mathrm{~cm}^{2}\right)$, what is due to the $\mathrm{RuO}_{2}$ metal oxide that generates micro, meso and macropores, and so greater surface roughness and higher capacitance $\left(C_{\mathrm{dl}}\right)$ values were obtained. At the same time, Al electrode showed the smallest EA $\left(33.3 \mathrm{~cm}^{2}\right)$ because it is a smooth and polished metal plate that exhibits the lowest $C_{d l}$ among all electrodes. It has generally been stated that for cathodes, greater EA is generally 
beneficial. Data in Table 2 show that for $\mathrm{Ti} / \mathrm{RuO}_{2}$ and $\mathrm{G}$ electrodes, $\mathrm{EA}$ are $2,167 \mathrm{~cm}^{2}$ and 1,560 $\mathrm{cm}^{2}$, respectively. This makes the $\mathrm{Ti} / \mathrm{RuO}_{2}$ electrode to be better cathode under the perspective of electroactive areas. Also, regarding the electroactive area, the Fe electrode having EA of 1,689 $\mathrm{cm}^{2}$ seems better than the Al electrode having $33.3 \mathrm{~cm}^{2}$. Although being indicative, the value of EA, however, is not a definitive factor for the choice of the most proper electrodes for EC.

Choice of better arrangement of electrodes by means of polarization curves

Aluminum electrode

Chronoamperometric, $i$ vs. $t$ responses of the Al electrode in acid way sample recorded during 45 min are presented in Figures 7 and 8. Similar behavior is observed at different potentials ( $E_{\text {app }}$ ) applied between -0.650 and $1,050 \mathrm{mV}$. As $E_{\text {app }}$ was increased, $i$ was increased in the same way. However, at very high $E_{\text {app }}(850$ and $1,050 \mathrm{mV}$ ) the decomposition of the medium is already occurring, which leads to unnecessary energy consumption. Figure 9 shows $i$ vs. $E_{\text {app }}$ responses for the Al electrode $\left(E A=33.3 \mathrm{~cm}^{2}\right.$ ) in the acid whey sample. It is obvious from Fig. 9 that the limiting current $\left(i_{1}\right)$ where diffusional control begins is reached at about $400 \mathrm{mV} v \mathrm{vs}$. SCE and that diffusional currents are in a range of 0.039 and $0.042 \mathrm{~A}$. Despite application of higher voltages, there are no greater transformations of the species present in the medium, up to the potential suitable for secondary reactions like the electrolysis of the water. Figure 10 shows the polarization curve, $\log j v s . \eta$, of the Al electrode. In this graph, it is observed that the limiting current is reached by diffusional control at overpotential of $200 \mathrm{mV}$. This suggests that from the results obtained previously during the EC with a removal efficiency of $79 \%$ in $8 \mathrm{~h}$, the energy required can be reduced (by decreasing $\eta$ from 1.74 to $0.2 \mathrm{~V}$ ) to obtain the same removal efficiency and possible reduction of time.

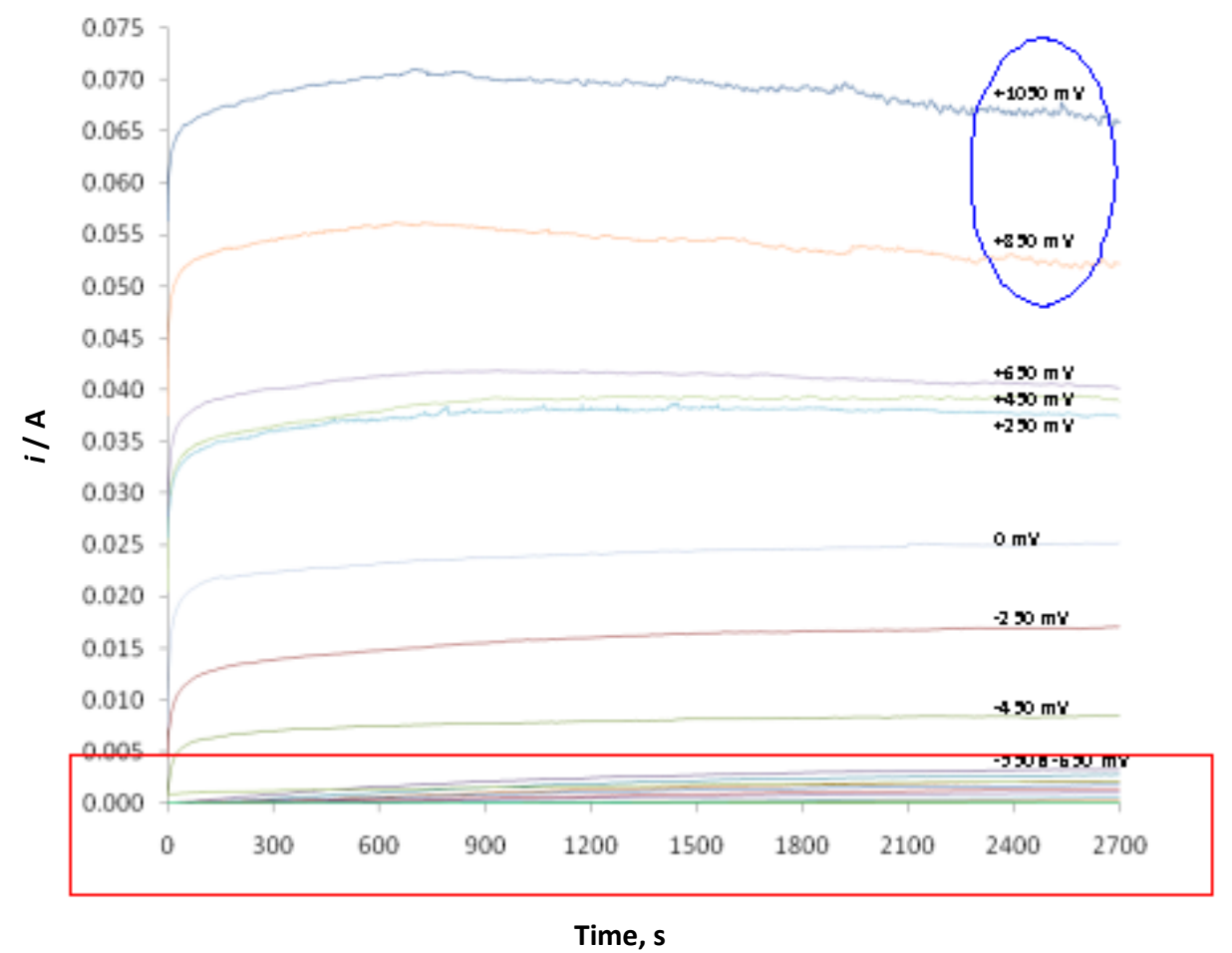

Figure 7. Chronoamperometric i vs. t responses of Al electrode in acid whey sample recorded during 45 minutes at $\mathrm{E}_{\text {app }}$ between $-650 \mathrm{mV}$ and $+1,050 \mathrm{mV}$ 


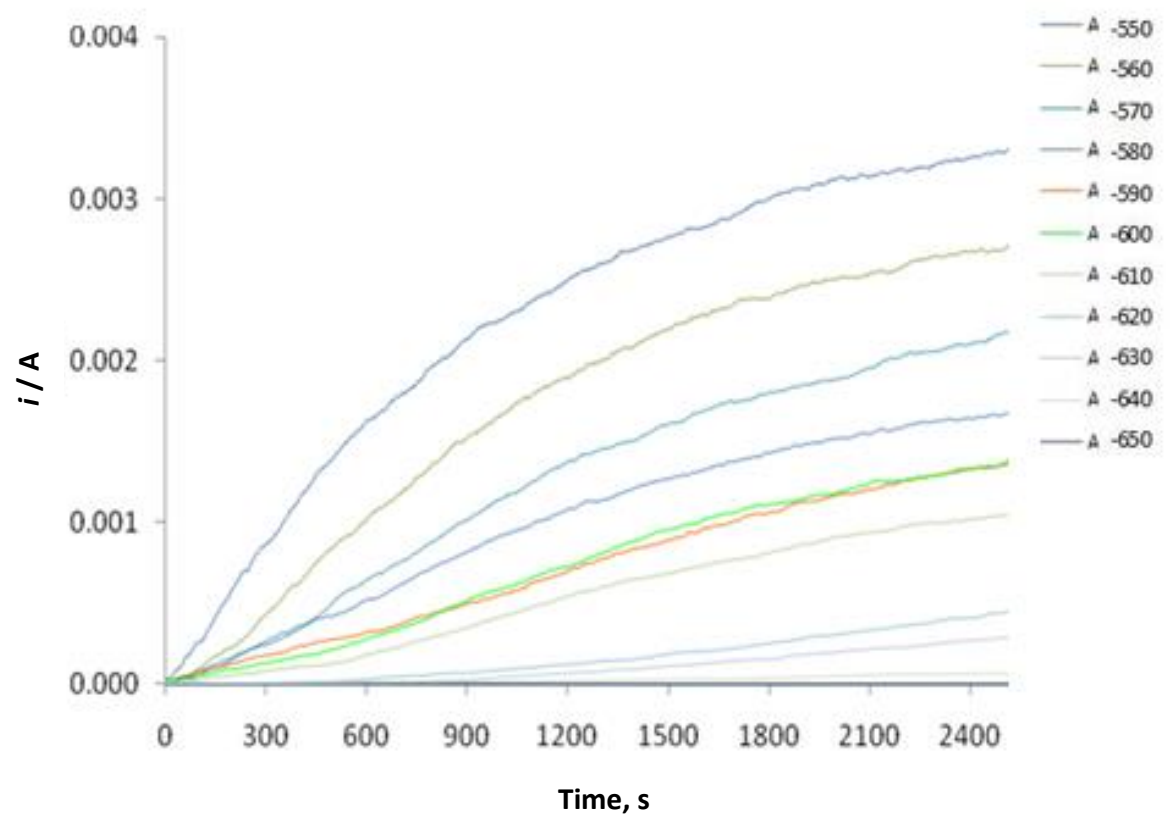

Figure 8. Chronoamperometric i vs. $t$ responses of Al electrode recorded at $\mathrm{E}_{\text {app }}$ between $-650 \mathrm{mV}$ and $-550 \mathrm{mV}$ (zoom of Fig. 7)

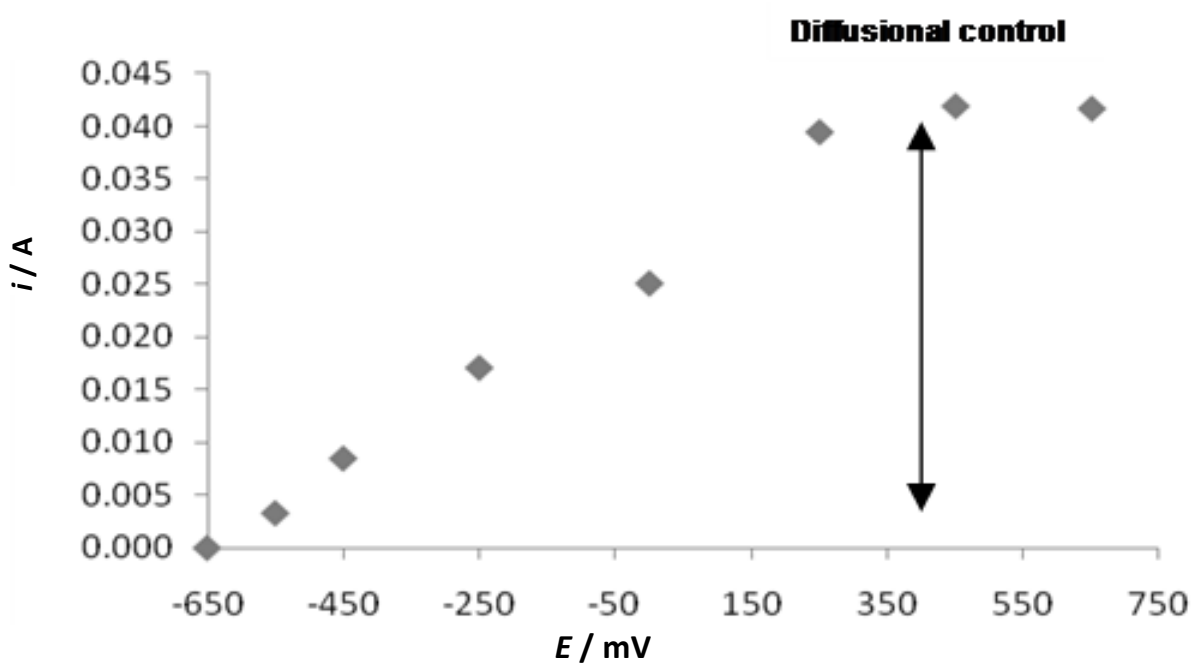

Figure 9. $\mathrm{i}$ vs. $\mathrm{E}_{\text {app }}$ of $\mathrm{Al}$ electrode in acid whey sample at $\mathrm{E}_{\text {app }}$ between $-650 \mathrm{mV}$ and $+650 \mathrm{mV}$

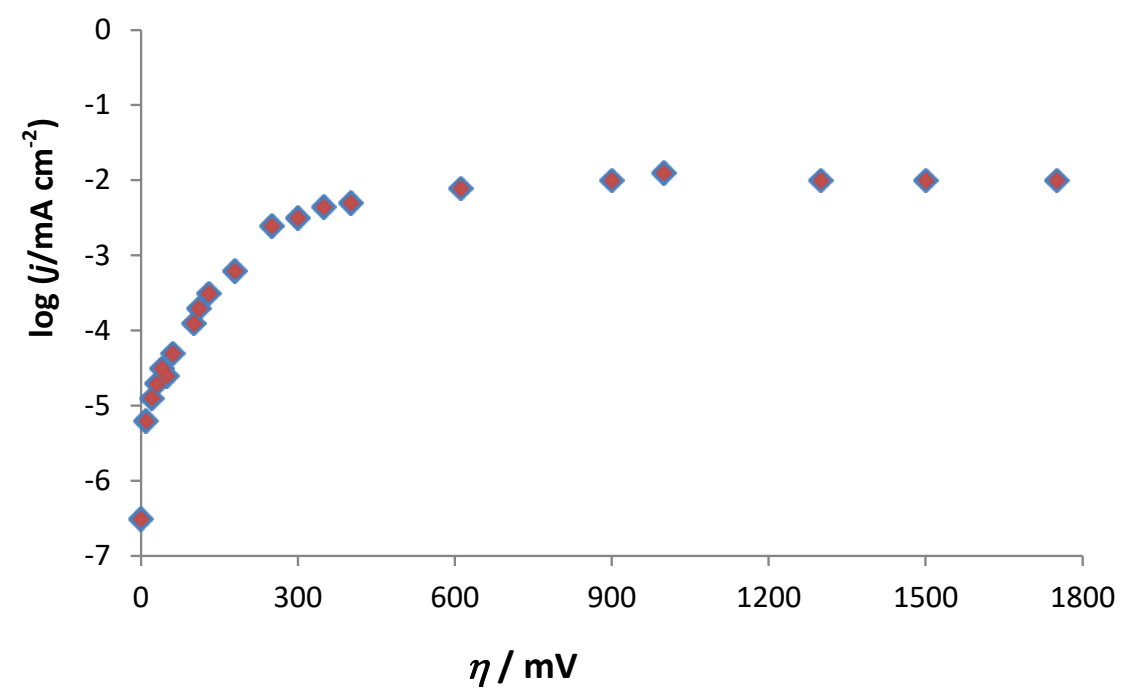

Figure 10. $\log \mathrm{j}$ vs. $\eta$ dependence of Al electrode in acid whey sample 


\section{Iron electrode}

The chronoamperometric, $i$ vs. $t$ curves of the Fe electrode in acid whey sample recorded during $45 \mathrm{~min}$ are shown in Figures 11 and 12. Almost constant current values observed with time at each $E_{\text {app }}$ applied between -650 and $-150 \mathrm{mV}$ suggest that only capacitive currents are generated at the Fe electrode in contact with the acid whey solution. When applying $E_{\text {app }}$ between 0 to $100 \mathrm{mV}$, however, the first change in the oxidation state of $\mathrm{Fe}^{\circ}$ to $\mathrm{Fe}^{2+}$ is observed with transfer of $2 \mathrm{e}^{-}$coupled with the decomposition of the medium. At $E_{\text {app }}$ between 100 to $450 \mathrm{mV}$, a second change in current is observed due to the electrochemical oxidation of $\mathrm{Fe}^{2+}$ to $\mathrm{Fe}^{3+}$, so that the oxidation of iron is considered to occur in two stages (eqs. 5 and 6):

$$
\begin{aligned}
& \mathrm{Fe}^{\circ} \rightarrow \mathrm{Fe}^{2+}+2 \mathrm{e}^{-} \\
& \mathrm{Fe}^{2+} \rightarrow \mathrm{Fe}^{3+}+1 \mathrm{e}^{-}
\end{aligned}
$$

Finally, by applying $E_{\text {app }}$ higher than $450 \mathrm{mV}$ the electrolysis of the medium that is decomposition of the whey begins, what is accompanied by the significant current increase with time. $i$ vs. $E_{\text {app }}$ and $\log$ j vs. $\eta$ dependences are presented in Figures 13 and 14. Here also, two different processes which are related to iron oxidation can be observed as in the chronoamperometry experiments. With these polarization curves it is verified that in the EC system, generation of $\mathrm{Fe}^{2+}$ or $\mathrm{Fe}^{3+}$ can be favored to improve the efficiency of the system in a shorter time and lower energy cost.

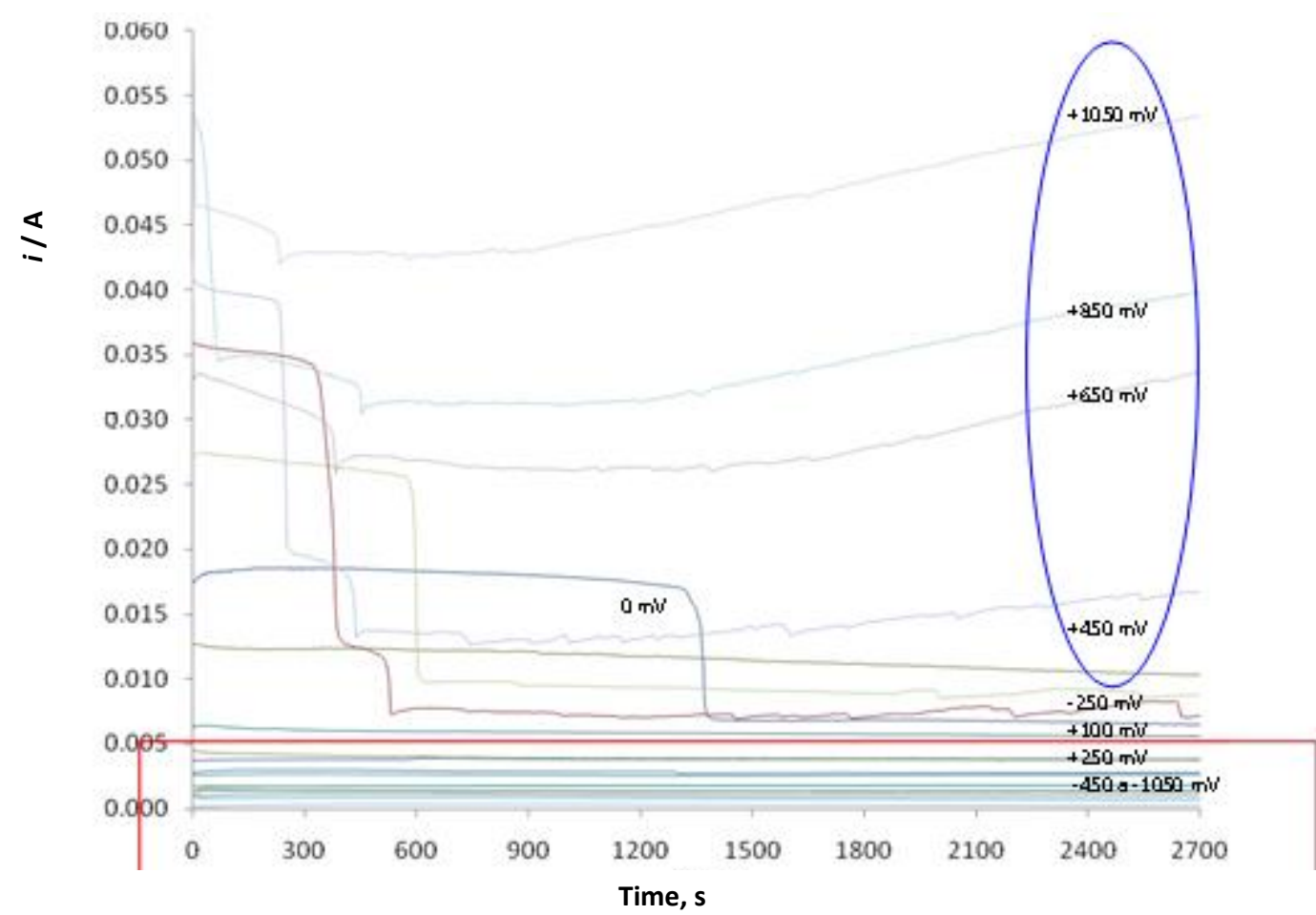

Figure 11. Chronoamperometric i vs. t responses of Fe electrode in acid whey sample recorded during 45 minutes at $\mathrm{E}_{\text {app }}$ between $-1050 \mathrm{mV}$ and $+1050 \mathrm{mV}$

The above statement can be based on the Pourbaix diagram for the thermodynamic states of the iron in aqueous solution, where when applying potentials within the range of 0.6 to $1.6 \mathrm{~V}$ vs. SCE, the oxidation process occurs and $\mathrm{Fe}^{2+}$ or $\mathrm{Fe}^{3+}$ ions are released depending on the $\mathrm{pH}$ of the solution. For acid conditions, both species are present and the process of corrosion is facilitated. It should be analyzed in more detail, however, which reaction would favor the EC process for the whey solution 
and formation of the iron oxy-hydroxides. Thus, one would be able to establish the optimum limiting current according to the limiting reagent that controls the reaction.

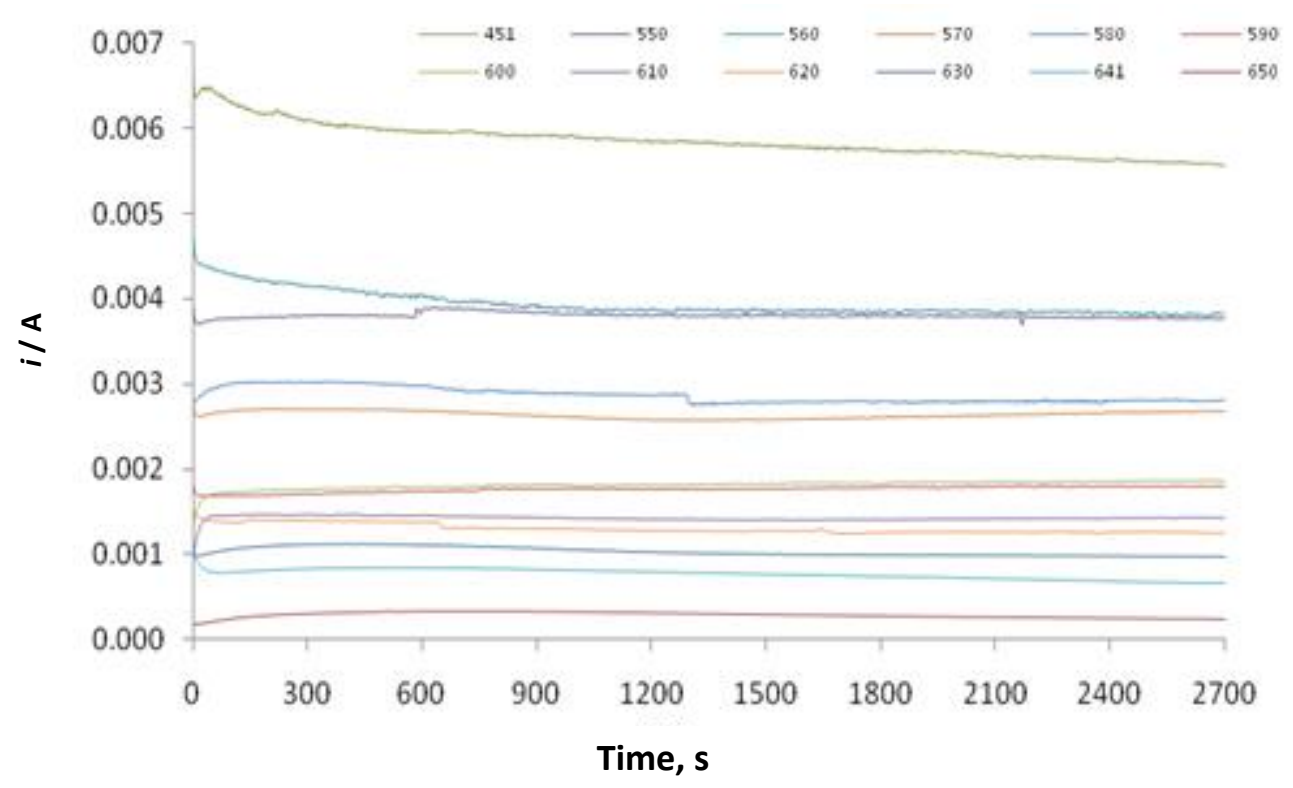

Figure 12. Chronoamperometric i vs. t responses of Fe electrode at $\mathrm{E}_{a p p}$ between $-650 \mathrm{mV}$ and $-450 \mathrm{mV}$ (zoom of Fig. 11)

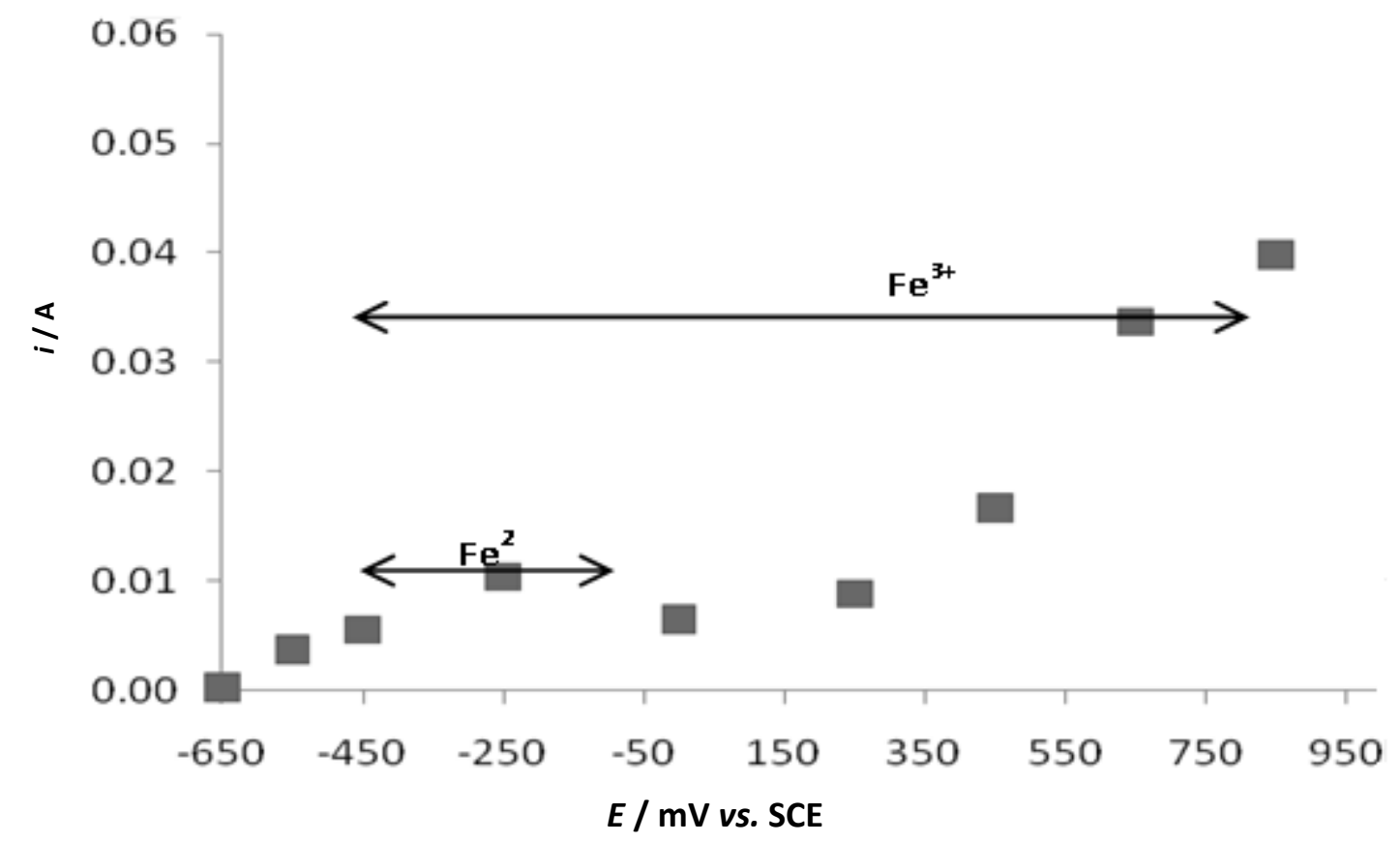

Figure 13. i vs. $\mathrm{E}_{\text {app }}$ of Fe electrode in acid whey sample at $\mathrm{E}_{\text {app }}$ between $-650 \mathrm{mV}$ and $850 \mathrm{mV}$

The bibliographical reports on the EC processes using iron electrodes are contradictory. Most EC studies have focused on the removal of contaminants by their co-precipitation with the solid(s) such are already formed precipitates of $\mathrm{Fe}(\mathrm{OH})_{2}(\mathrm{~s})$ and $\mathrm{Fe}(\mathrm{OH})_{3}(\mathrm{~s})$. Also, the reactions reported in the literature showed a certain ambiguity in the proposed mechanisms. Some studies [13-15] have reported that the oxidation of iron $\mathrm{Fe}^{0}$ to $\mathrm{Fe}^{2+}$ occurs in an electrolytic form and produces insoluble $\mathrm{Fe}(\mathrm{OH})_{2}(\mathrm{~s})$ compounds by hydrolysis. Other authors [16] pointed to the formation of $\mathrm{Fe}(\mathrm{OH})_{2}(\mathrm{~s})$ without giving details of how it occurs. Several studies $[8,17,18]$ reported formation of $\mathrm{Fe}^{2+}$ at the anode that is followed by oxidation to $\mathrm{Fe}^{3+}$ due to dissolved oxygen (DO) and rapid formation of $\mathrm{Fe}(\mathrm{OH})_{3}(\mathrm{~s})$. The third mechanism reported $[7,8,10]$ involves the single and fast electrolytic oxidation 
step of $\mathrm{Fe}^{0}$ to $\mathrm{Fe}^{3+}$, followed by hydrolysis to produce $\mathrm{Fe}(\mathrm{OH})_{3}(\mathrm{~s})$. Finally, some studies $[16,19,20]$ have reported formation of $\mathrm{Fe}(\mathrm{OH})_{3}(\mathrm{~s})$ as the final product during $\mathrm{EC}$ without specifying the reactions involved. According to [21], the third mechanism is questionable. These authors pointed out dependence of the kinetics of these reactions on the $\mathrm{pH}$ of the medium. They reported that at $\mathrm{pH} 7.5$, approximately $80 \%$ of the $\mathrm{Fe}^{2+}$ initially formed is oxidized to $\mathrm{Fe}^{3+}$ in less than 10 minutes, while at $\mathrm{pH} 6.5$, the same oxidation process takes about 300 minutes $(5 \mathrm{~h})$. The rapid increase in $\mathrm{Fe}^{2+}$ oxidation rate with $\mathrm{pH}$ increase is consistent with other reports in the literature, where based on equations (7) and (8), it was shown that increase of $\mathrm{pH}$ increases the oxidation rate of $\mathrm{Fe}^{2+}$ for about 100 times [22-24].

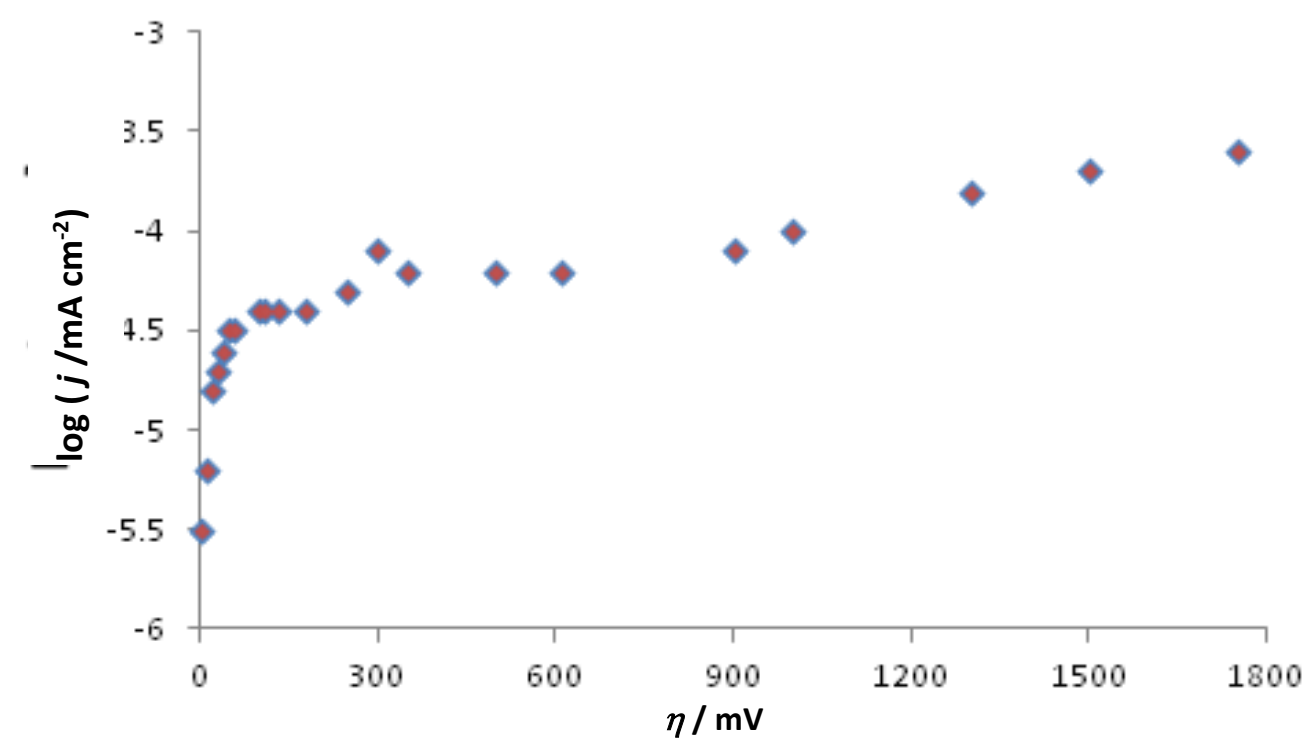

Figure 14. Log j vs. $\eta$ dependence of Fe electrode in acid whey sample.

$$
\begin{aligned}
& 4 \mathrm{Fe}^{2+}+\mathrm{O}_{2}+2 \mathrm{H}_{2} \mathrm{O}+8 \mathrm{OH}^{-} \leftrightarrow 4 \mathrm{Fe}(\mathrm{OH})_{3}(\mathrm{~s}) \\
& \mathrm{d}\left[\mathrm{Fe}^{2+}\right] / \mathrm{d} t=-k\left[\mathrm{Fe}^{2+}\right] P_{\mathrm{O}_{2}}\left[\mathrm{OH}^{-}\right]^{2}
\end{aligned}
$$

In eq. (8), $k$ is the rate constant, $P_{\mathrm{O} 2}$ is the oxygen partial pressure, while the molar concentrations of present species are represented in the brackets.

A slight increase in the concentration of $\mathrm{OH}^{-}$ions as observed during $\mathrm{EC}$ and corroborated with the increase of $\mathrm{pH}$, has resulted in a greater concentration of the $\mathrm{Fe}^{2+}$ species forming $\mathrm{Fe}^{3+}$ by subsequent oxidation and $\mathrm{Fe}(\mathrm{OH})_{3}(\mathrm{~s})$ by precipitation. Since $\mathrm{OH}^{-}$ions are consumed during the hydrolysis of $\mathrm{Fe}^{3+}, \mathrm{pH}$ in the electrolytic cell decreases in a subsequent step that does not occur immediately. By the time elapsed between the production of $\mathrm{Fe}^{2+}$ and its oxidation to $\mathrm{Fe}^{3+}$ by the oxygen dissolved in the medium, a reaction that is much slower has been indicated.

\section{Graphite electrode}

In Figures 15 and 16, the chronoamperometric $i$ vs. $t$ responses of the $G$ electrode recorded through $45 \mathrm{~min}$ are presented, showing the same behavior at different $E_{a p p}$ applied. As $E_{a p p}$ increases, $i$ increased in the same way. At very negative $E_{\text {app }}(-1050 \mathrm{mV})$, however, it can be observed that the decomposition of the medium occurs. By presenting log $j$ vs. $\eta$ dependence, Fig. 17 suggests that the limiting current $\left(i_{l}\right)$ is occurring at overpotential of $-500 \mathrm{mV}$, where diffusional control begins. 


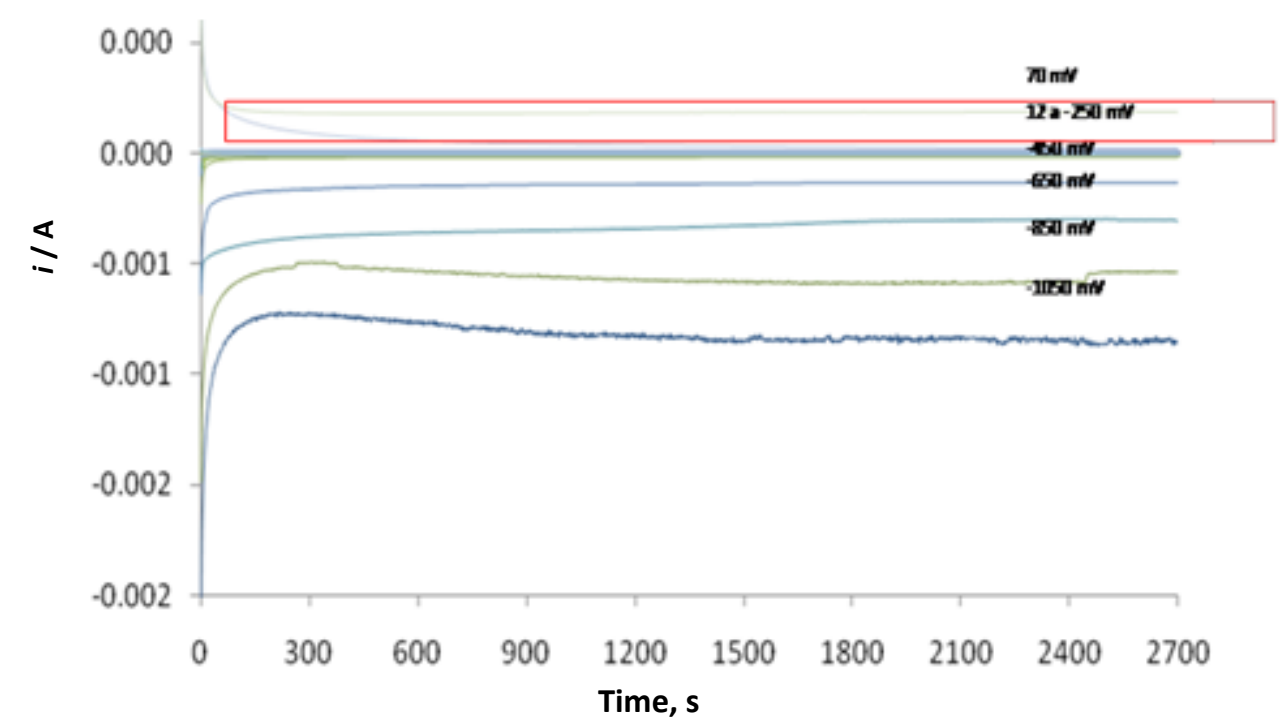

Figure 15. Chronoamperometric i vs. $t$ responses of $G$ electrode in acid whey sample recorded during $45 \mathrm{~min}$ at $\mathrm{E}_{\text {app }}$ between $70 \mathrm{mV}$ and $-1050 \mathrm{mV}$.

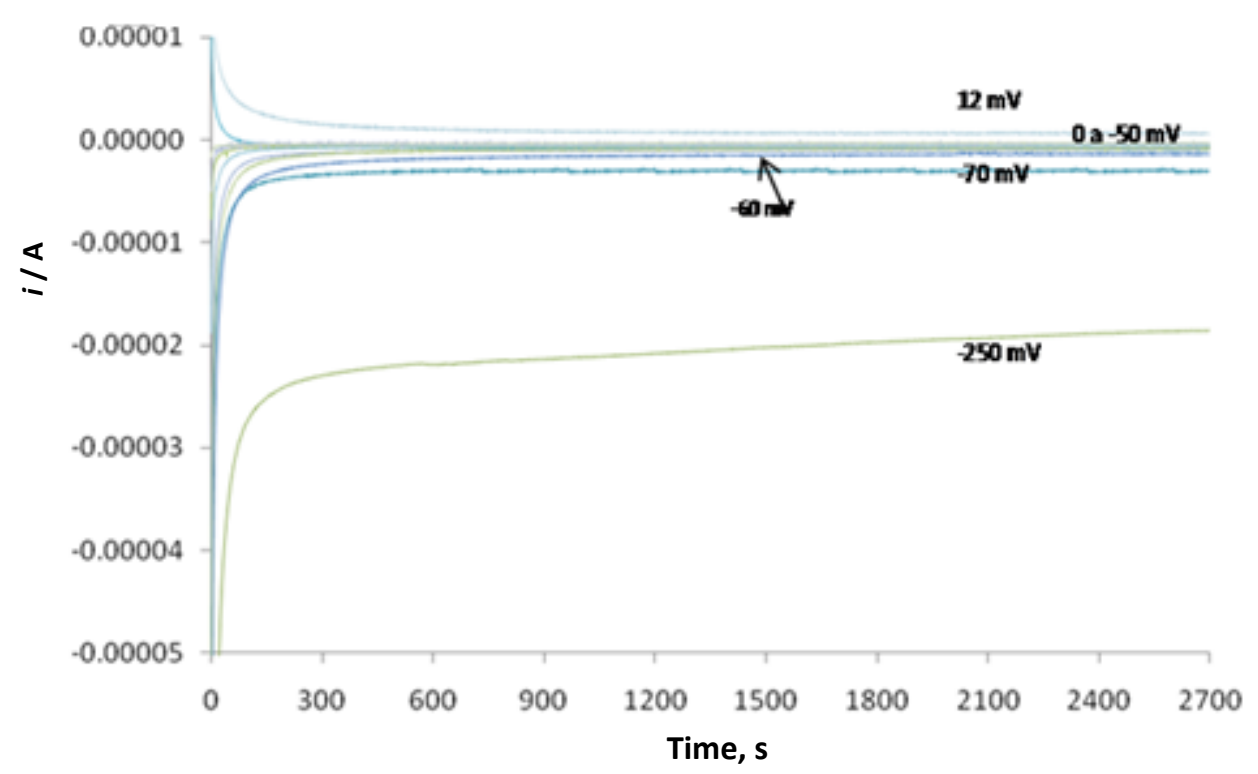

Figure 16. Chronoamperometric i vs. $t$ responses of the $G$ electrode at $\mathrm{E}_{\text {app }}$ between $12 \mathrm{mV}$ and $-250 \mathrm{mV}$ (zoom of Fig. 15)

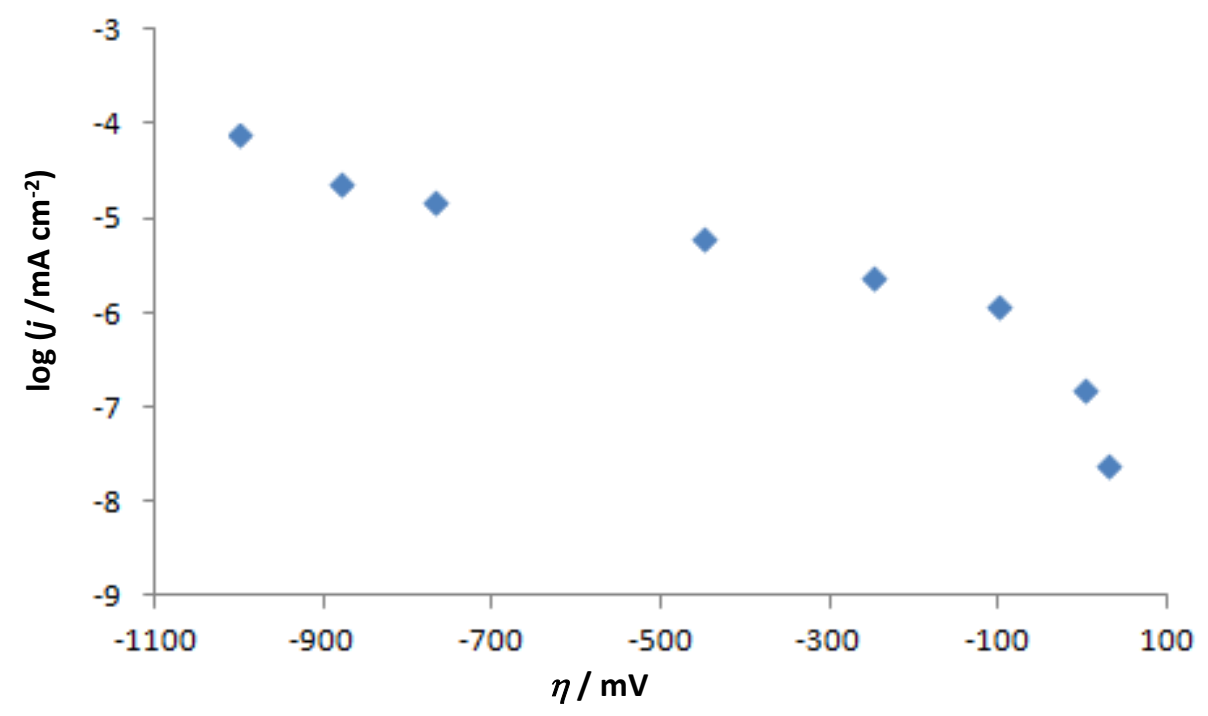

Figure 17. $\log \mathrm{j}$ vs. $\eta$ dependence of $G$ electrode in acid whey sample. 
Selection of the anodic material for the electrocoagulation process.

With the electrochemical information obtained so far, the Tafel slopes for the electrodes acting as sacrificial anodes (Al and Fe) are compared in Figure 18.

To select the best electrode, the largest slope must be taken into account. The results for Fe and Al electrodes are different, for the Al electrode, $b=-54.55 \mathrm{mV} \mathrm{dec}{ }^{-1}$ and for Fe, $b=-109.98 \mathrm{mV} \mathrm{dec}^{-1}$. In this respect, it is possible to define that the Fe electrode is considered the most effective. Figure 19 shows a better separation of the precipitate and purified liquid more transparent with the use of the Fe electrode (Figure 19 a).

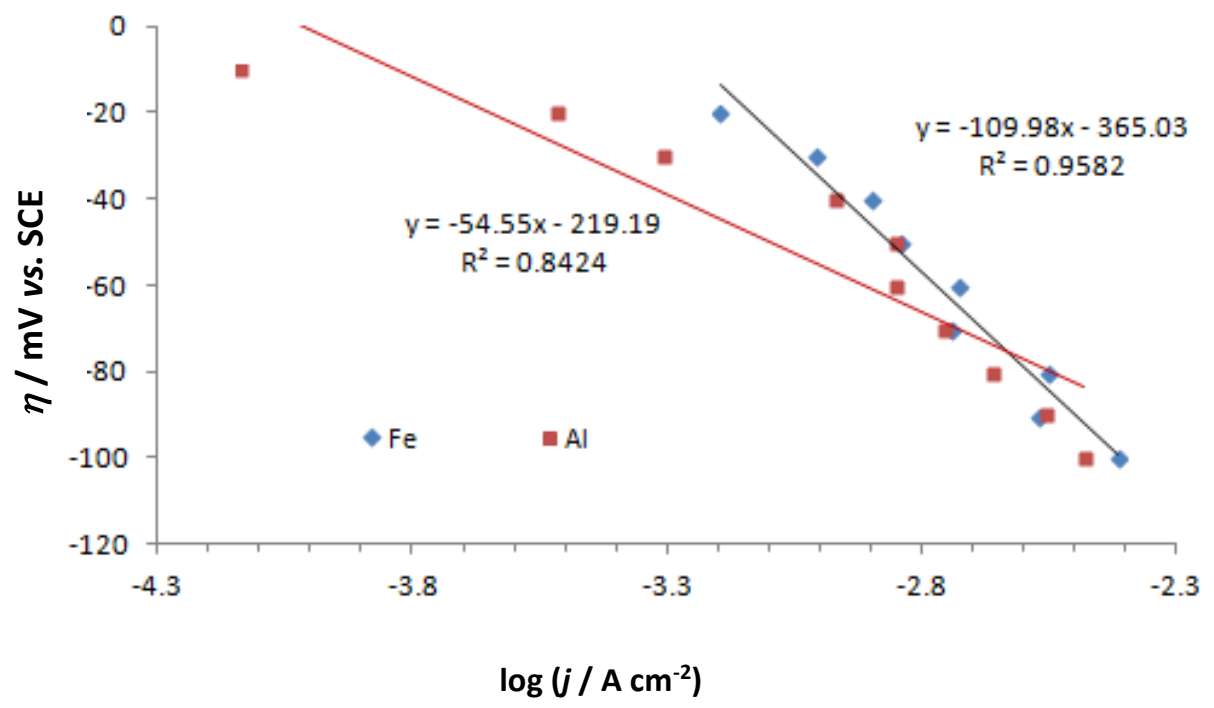

Figure 18. Tafel slopes of Fe and Al electrodes in acid whey samples

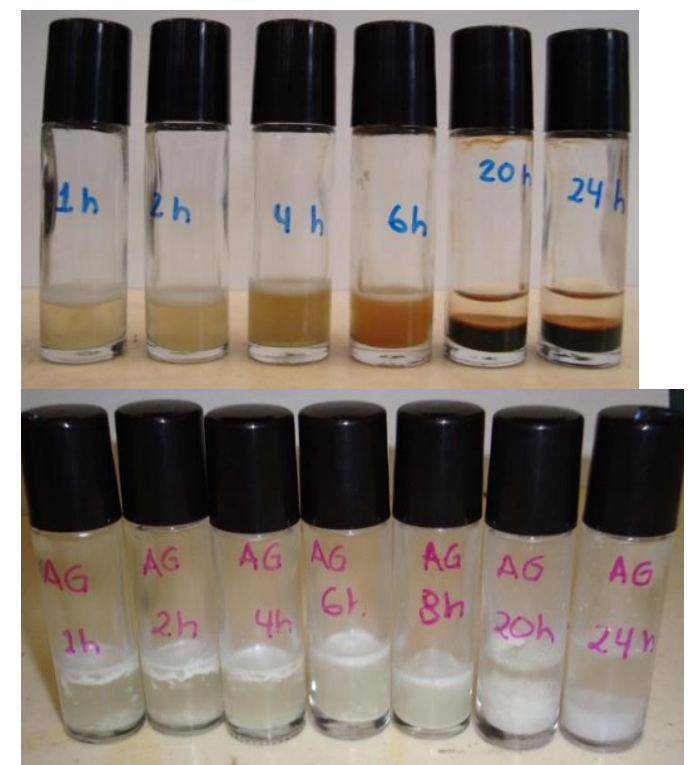

a)

Figure 19. Purification kinetics of acid whey with $\mathrm{Fe}(a)$ and $\mathrm{Al}(\mathrm{b})$ electrodes

\section{Conclusions}

The iron electrode proved to be better anode than Al for the EC process. This is due to its stable thermodynamic behavior in the range of applied overpotentials, which translates into a greater transfer of charge in a shorter time. By correlating these results with the results obtained during the preliminary tests, it can be confirmed that the Fe electrode is better than the Al electrode. With the Fe electrode, greater removals (79 are obtained in less time $(8 \mathrm{~h})$ ). On the other hand, with the Al 
electrode, the results of macroelectrolysis required more time ( $24 \mathrm{~h})$ to achieve an efficiency of 49 $\%$. Based on the determinations of the electroactive area, the $\mathrm{Ti} / \mathrm{RuO}_{2}$ electrode $\left(2,167 \mathrm{~cm}^{2}\right)$ proved to be a better cathode than the graphite $\left(1,560 \mathrm{~cm}^{2}\right)$.

\section{References}

[1] M. Piña, A. Martín, C. A. González, F. Prieto, A. Guevara, J. E. García. Revista Mexicana de Ingeniería Química 10(2) (2011) 257-271.

[2] A. P. Restrepo, A. Arango, L. F. Garcés. Producción + Limpia 1(2) (2006) 58-77.

[3] E. Ojeda, R. Hing, Y- González. Revista CENIC Ciencias Químicas 43(1) (2912), 21-42.

[4] S. Tchamango, E. Nanseu-Njiki, D. Ngameni, A. Hadjiev, A Darchen. Science of the Total Environment 408 (2010) 947-952.

[5] P. Panesar, J. Kennedy, D. Gandhi, K. Bunko, Food Chemistry 105 (2007) 1-14.

[6] A. Abaigar, ITG Ganadero 94(8) (2009) 13-17.

[7] N, Balasubramanian, K. Madhavan, Chemical Engineering Technology 24 (2001) 519-521.

[8] M. Y. Mollah, P. G. Morkovsky, A. G. Gomes, M. Kesmez, J. Parga, Journal of Hazardous Materials 114(1-3) (2004) 199-210.

[9] O. T. Can, M. Bayramoglu, M. Kobya. Industrial Engineering Chemistry Research 42 (2003) 3391-6.

[10] M. Kobya, O. T. Can, M. Bayramoglu. Journal of Hazardous Materials B1001 (2003) 63-78.

[11] H. Inan, A. Dimoglo, H. Simsek, M. Karpuzku. Separation and Purification Technology 36 (2004) 23-31.

[12] G. Chen, Separation and Purification Technology 38(1) (2004) 11-41.

[13] V. P. Osipenko, P. I. Pogorelyi. Metallurgist 21(9-10) (1977) 44-45.

[14] M. Y. Mollah, R. Schennach, J. R. Parga, D. L. Cocke. Journal of Hazardous Materials 84(1) (2001) 29-41.

[15] R. Parga, D. L. Cocke, V. Valverde. Cheical Engineering Technology 28(5) (2005) 605-612.

[16] D. Ghernaouta, A. Badisa, A. Kellila, A. Desalination 219(1-3) (2008) 118-125.

[17] X. M. Chen, G. Chen, P. L. Yue. Separation and Purification Technology 19(1) (2000) 65-76.

[18] H. K. Hansen, P. Núñez, R. Grandon. Minerals Engineering 19(5) (2006) 521-524.

[19] D- Mills, Journal American Water Works Association 92(6) (2000) 34-43.

[20] P. R. Kumar, S. Chaudhari, K. Khilar, S. P. Mahajan. Chemosphere 55(9) (2004) 1245-1252.

[21] D. Lakshmanan, D. Clifford, and S. Gautam. Environmental Science Technology 43 (2009) 3853-3859.

[22] P. C. Singer, W. Stumm. Journal American Water Works Association 62 (1970) 198-202.

[23] W. Stumm, S. Morgan, Journal. Aquatic Chemistry; 1981. Wiley-Interscience, New York.

[24] M. Bond, S. Kratsis and S. Mitchell. Journal Analyst 122 (1997) 1147-1152.

(C) 2017 by the authors; licensee IAPC, Zagreb, Croatia. This article is an open-access article distributed under the terms and conditions of the Creative Commons Attribution license (http://creativecommons.org/licenses/by/4.0/) 